\title{
PERBANDINGAN PASSIVE LC FILTER DAN PASSIVE SINGLE TUNED FILTER UNTUK MEREDUKSI HARMONISA VARIABLE SPEED DRIVE DENGAN BEBAN MOTOR INDUKSI TIGA FASA
}

\author{
Mustamam ${ }^{1)}$, Usman Baafai ${ }^{2)}$, Marwan Ramli ${ }^{3)}$
}

\begin{abstract}
ABSTRAK
Sebagian besar alat yang digunakan sebagai pengatur kecepatan putaran motor induksi tiga fasa adalah Variable Speed Drive (VSD) 1 fasa, di mana VSD merupakan pembangkit harmonisa. Oleh sebab itu harmonisa yang timbul pada VSD dapat direduksi dengan menggunakan filter fasif yaitu passive LC filter dan passive single tuned filter sehingga memenuhi standar IEC61000-3-2 kelas A. Hasil yang diperoleh dengan passive LC filter dapat mengurangi total distorsi harmonisa arus (THDi) dari 102,9\% menjadi 23,78\% sedangkan passive single tuned filter mengurangi total distorsi harmonisa arus (THDi) dari 102,9\% menjadi 8,79\%. Pada harmonisa ke 5 passive LC filter dapat mengurangi harmonisa dari 1,26 Amper menjadi 0,16 Amper, sedang passive single tuned filter dari 1,26 Amper menjadi 0,111 Amper. Impedansi yang dihasilkan passive single tuned filter lebih kecil yaitu 0,436 $\Omega$ sedang passive LC filter 8,34 $\Omega$. Dengan demikian passive single tuned filter lebih baik untuk mereduksi harmonisa dibandingkan dengan passive LC filter.
\end{abstract}

Kata Kunci : Variable speed drive 1 fasa, motor induksi 3 fasa, harmonisa, passive LC filter, passive single tuned filter.

\section{ABSTRACT}

Most of the tools that used as speed control of three phase induction motors rotation is 1 phase Variable Speed Drive (VSD), where VSD is a harmonic generator. Therefore the harmonics that arise in the VSD can be reduced by using passive LC filters fasif namely passive single tuned filter that meet the standards IEC61000-3-2 Class A.The results obtained through passive LC filter could reduce the total distortion of harmonic current (THDi) from $102.9 \%$ to $23.78 \%$ while passive single tuned filter reduced the total harmonic distortion current (THDi) from $102.9 \%$ to $8.79 \%$. At the fifth harmonics passive LC filters could reduce the harmonics current from 1.26 Ampere to 0.16 Ampere, while passive single tuned filter could reduce the harmonic current from 1.26 Amper to 0.111 Amper. The impedance produced by passive single tuned filters was smaller that is $0.436 \Omega$ while passive LC filters was $8.34 \Omega$. There by passive single tuned filter is better to reduce harmonics than passive LC filters is.

Keywords: 1-phase Variable Speed Drive, 3-phase induction motor, harmonics, passive LC filters, passive single tuned filters.

\section{Pendahuluan}

Motor induksi tiga fasa cukup banyak digunakan sebagai penggerak utama mesin-mesin di dunia industri. Hal ini dikarenakan motor induksi mempunyai keuntungan antara lain, bentuknya yang sederhana, konstruksinya cukup kuat, harganya relatif murah dan kehandalannya tinggi. Namun yang menjadi kelemahannya adalah tidak mampu mempertahankan kecepatannya dengan konstan bila terjadi perubahan beban. Untuk mendapatkan kecepatan konstan serta memperbaiki kinerja motor induksi, maka dibutuhkan pengaturan kecepatan putaran motor. Sebagian besar alat yang digunakan sebagai pengatur kecepatan putaran motor induksi tiga fasa adalah Variable Speed Drive (VSD) [1],[2],[3].

VSD merupakan suatu peralatan di mana komponennya merupakan beban non linear yang menghasilkan bentuk gelombang arus dan tegangan sinusoidal yang tidak murni yang akan menghasilkan harmonisa dan dapat menimbulkan kerugian, seperti: menurunkan kualitas sistem tenaga listrik , penurunan faktor daya, naiknya distorsi terhadap input, kegagalan fungsi dari peralatan elektronik yang sensitif, menurunkan efisiensi [1]. Banyaknya pemasangan VSD menyebabkan timbulnya harmonisa yang tersambung pada sumber yang sama. Untuk menurunkan harmonisa dapat dilakukan dengan menggunakan filter pasif seperti passive LC filter maupun passive single tuned filter.

Penelitian yang diajukan pada tesis ini adalah perbandingan pemasangan passive $L C$ filter dan passive single tuned filter pada sisi input VSD tipe ATV12H075 dengan daya 750 Watt untuk dapat mengurangi harmonisa dengan program simulasi menggunakan software MATLAB/ Simulink.

\section{Motor Induksi Tiga Fasa}

Motor induksi adalah suatu mesin listrik yang merubah energi listrik menjadi energi gerak dengan menggunakan gandengan medan listrik dan mempunyai slip antara medan stator dan medan rotor. Arus motor ini didapat secara induksi atau imbas, sebagai akiba 
Perbandingan Passive Lc Filter Dan Passive Singletuned Filter Untuk Mereduksi Harmonisavariable Speed Drive Dengan Beban Motor Induksi Tiga Fasa

adanya perbedaan relatif antara putaran rotor dan medan putar yang dihasilkan oleh arus stator.

Bila sumber tegangan tiga fasa dipasang pada kumparan medan stator, maka akan timbul medan putar dengan kecepatan $(n)$ yang ditunjukan pada Persamaan 1 [13],[14] :

$n=\frac{120 f}{P}$

Perbedaan kecepatan antara medan putar stator dengan perputaran rotor tersebut disebut dengan slip (S) dan dinyatakan dengan Persamaan (2) [2] :

$$
S=\frac{n_{s}-n_{r}}{n_{s}} \times 100 \%
$$

Persamaan (2) dapat ditulis dengan Persamaan ( 3)

$\mathrm{n}_{\mathrm{r}}=\mathrm{n}_{\mathrm{r}} \frac{120 \mathrm{f}_{\mathrm{s}}}{\mathrm{P}}(1-\mathrm{S})$

\section{Pengaturan kecepatan motor induksi}

Pengaturan kecepatan motor induksi dapat dilakukan dengan beberapa cara mengacu pada Persamaan (1), [3]:

a. Mengubah jumlah kutub motor

b. Mengubah frekuensi jaringan

c. Mengubah resistansi tahanan rotor

d. Mengubah besarnya slip

Cara dengan mengubah frekuensi jaringan adalah yang paling umum digunakan yaitu dengan inverter [3].

\section{Variable Speed Drive (VSD)}

VSD atau juga disebut dengan Variable Frequency Drive atau inverter adalah mempunyai kemampuan untuk pengaturan motor sesuai bebannya atau sesuai dengan kecepatan yang diinginkan. Salah satu jenis VSD yang sering digunakan adalah tipe ATV12H075M2 pada Gambar 1 [12].

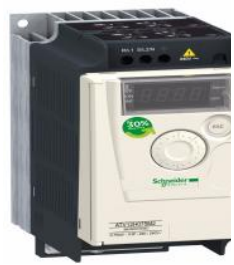

Gbr 1. Variable Speed Drive (VSD) tip ATV12H075M2

Secara sederhana untuk drive AC, Variable Speed Drive atau inverter akan mengubah AC ke DC yang kemudian diatur dengan suatu teknik penyaklaran 'switching'. Ada tiga jenis inverter yaitu [15]:

\section{a. Variable voltage inverter (VVI)}

Jenis inverter ini menggunakan konverter jembatan SCR untuk mengubah tegangan input AC ke DC. Memiliki kemampuan untuk mengatur nilai tegangan DC mulai dari 0 hingga mendekati 600 VDC. Gambar 2 rangkaian variabel inverter tegangan.

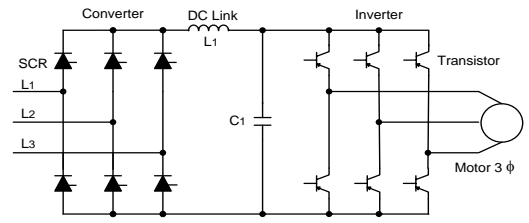

Gbr 2. Rangkaian variabel inverter tegangan

\section{b. Current source inverter (CSI)}

Jenis inverter satu ini menggunakan SCR untuk menghasilkan tegangan DC-link yang bervariasi untuk suplai ke bagian inverter seperti pada Gambar 3. Beda dengan VVI yang mengontrol tegangan, CSI justru mengontrol arus yang akan disuplai ke motor.

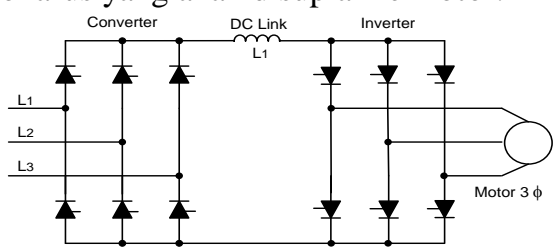

Gbr 3. Skema sumber inverter arus

\section{c. Pulse width modulation}

Teknik penyaklaran memberikan output yang lebih sinusoidal dibandingkan dua jenis inverter sebelumnya. Drive yang menggunakan PWM lebih efisien dan memberikan performa yang lebih tinggi. Biasanya konverter yang digunakan adalah tipe tidak terkontrol (dioda biasa) namun ada yang menggunakan setengah terkontrol atau kontrol penuh [15].

Bentuk rangkaian dan prinsip kerja dari penyearah PWM satu fasa seperti yang pada Gambar 4 [17].

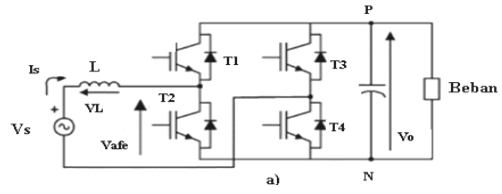

Gbr 4. Penyearah PWM satu fasa full bridge.

\section{Harmonisa}

Harmonisa adalah gangguan yang terjadi pada sistem distribusi tenaga listrik akibat terjadinya distorsi gelombang arus dan tegangan. Misalnya, frekuensi dasar suatu sistem tenaga listrik adalah $50 \mathrm{~Hz}$, maka harmonisa keduanya adalah gelombang dengan frekuensi $100 \mathrm{~Hz}$, harmonisa ketiga adalah gelombang dengan frekuensi sebesar $150 \mathrm{~Hz}$ dan seterusnya. Gelombang-gelombang ini kemudian menumpang pada gelombang murni/aslinya sehingga terbentuk gelombang cacat seperti pada Gambar 5 [18].

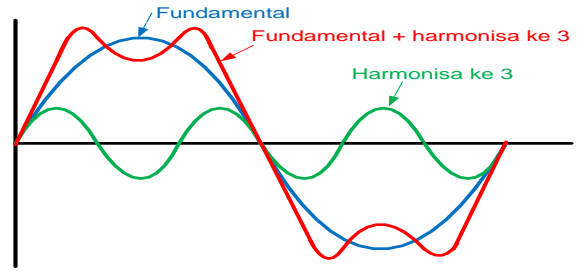

Gbr 5.Gelombang fundamental dengan gelombang harmonisanya [18]. 


\section{Perhitungan Harmonisa}

Untuk menentukan besar Total Harmonic Distortion (THD) dari perumusan analisa deret Fourier untuk tegangan dan arus dalam fungsi waktu yaitu [19]: $\mathrm{v}(\mathrm{t})=\mathrm{Vo}+\sum_{n=1}^{\infty} V_{n} \operatorname{Cos}\left(n \omega t+\theta_{n}\right)$

$i(t)=\mathrm{Vo}+\sum_{n=1}^{\infty} I_{n} \operatorname{Cos}\left(n \omega t+\theta_{n}\right)$

Tegangan dan arus $R M S$ dari gelombang sinusoidal yaitu nilai puncak gelombang dibagi $\sqrt{2}$ dan secara deret Fourier untuk tegangan dan arus yaitu [20]:

$\mathrm{V}_{\mathrm{RMS}}=\mathrm{V}_{\mathrm{o}}{ }^{2}+\sqrt{\sum_{n=1}^{\infty}\left(\frac{V_{n}}{\sqrt{2}}\right)^{2}}$
$\mathrm{I}_{\mathrm{RMS}}=\mathrm{I}_{\mathrm{o}}{ }^{2}+\sqrt{\sum_{n=1}^{\infty}\left(\frac{I_{n}}{\sqrt{2}}\right)^{2}}$

Untuk THD tegangan dan arus didefenisikan sebagai nilai RMS harmonisa urutan diatas frekuensi fundamental dibagi dengan nilai $R M S$ pada frekuensi fundamentalnya, dan tegangan DC nya diabaikan.

Besar THD untuk tegangan dan arus ditunjukan pada persamaan (8) dan (9) yaitu :

$T H D_{v}=\frac{\sqrt{\sum_{n=2}^{\infty}\left(\frac{V_{n}}{\sqrt{2}}\right)^{2}}}{\frac{V_{1}}{\sqrt{2}}}=\frac{\sqrt{\sum_{n=2}^{\infty}(V n)^{2}}}{V_{1}}$
$T H D_{I}=\frac{\sqrt{\sum_{n=2}^{\infty}\left(\frac{I n}{\sqrt{2}}\right)^{2}}}{\frac{I_{1}}{\sqrt{2}}}=\frac{\sqrt{\sum_{n=2}^{\infty}\left(I_{n}\right)^{2}}}{I_{1}}$

Hubungan Persamaan THD dengan arus RMS dari Persamaan (8) yaitu:

$$
\begin{aligned}
I_{R M S}{ }^{2} & =\frac{1}{2} \sum_{n=1}^{\infty} I_{n}^{2} \\
T H D_{I}{ }^{2} & =\frac{\frac{1}{2} \sum_{n=2}^{\infty} I^{2}{ }_{n}}{\frac{I^{2}{ }_{1}}{2}}=\frac{\sum_{n=1}^{\infty} I_{n}^{2}-I_{1}^{2}}{I_{1}{ }^{2}}
\end{aligned}
$$

Selanjutnya di dapat Persamaan (10) yaitu:

$$
\begin{aligned}
& I_{R M S}{ }^{2}=I_{1, R M S}{ }^{2}\left(1+\text { THD }_{I}^{2}\right) \\
& \frac{1}{2} \sum_{n=1}^{\infty} I_{n}{ }^{2}=\frac{I_{1}^{2}}{2}\left(1+T H D_{I}^{2}\right)
\end{aligned}
$$

Sehingga arus $R M S$ terhadap $T H D_{I}$ yaitu:

$$
I_{R M S}^{2}=I_{1, R M S}^{2} \sqrt{\left(1+T H D_{I}^{2}\right)}
$$

Individual Harmonic Distortion (IHD) adalah perbandingan nilai $R M S$ pada orde harmonisa terdistorsi terhadap nilai RMS pada frekuensi fundamental yaitu :

$$
\begin{aligned}
& I H D_{v}=\frac{\frac{V_{h}}{\sqrt{2}}}{\frac{V_{1}}{\sqrt{2}}}=\frac{V h}{V_{1}} \\
& I H D_{i}=\frac{\frac{I h}{\sqrt{2}}}{\frac{I_{1}}{\sqrt{2}}}=\frac{I_{h}}{I_{1}}
\end{aligned}
$$

Hubungan Persamaan IHD dengan arus RMS dari Persamaan (14) yaitu:

$$
\begin{aligned}
& I_{R M S}{ }^{2}=\frac{1}{2} I^{2}{ }_{n} \\
& I H D_{i}{ }^{2}=\frac{\frac{1}{2} I^{2} n}{\frac{I^{2} 1}{2}}=\frac{I^{2} n^{-} I^{2}{ }_{1}}{I_{1}{ }^{2}}
\end{aligned}
$$

Selanjutnya dari Persamaan (2.22) di dapat yaitu:

$I_{n}^{2}=I_{1}{ }^{2}+I_{1}{ }^{2} \cdot I H D_{i}{ }^{2}=I_{1}{ }^{2}\left(1+I H D_{i}{ }^{2}\right)$

$\frac{1}{2} I_{n}{ }^{2}=\frac{I_{1}{ }^{2}}{2}\left(1+I H D_{i}{ }^{2}\right)$

Sehingga arus $R M S$ terhadap $I H D_{i}$ yaitu:

$I_{R M S}{ }^{2}=I_{1 R M S}{ }^{2} \sqrt{\left(1+I H D_{i}^{2}\right)}$

\section{Batasan Harmonisa}

Untuk mengurangi harmonisa pada suatu sistem secara umum dengan mereduksi sebagian harmonisa sehingga diperoleh nilai dibawah standar yang diizinkan. Dalam mereduksi harmonisa diperhatikan secara teknis dibawah standar yang diizinkan dan tidak membutuhkan biaya yang besar. Standar yang digunakan sebagai batasan harmonisa adalah yang dikeluarkan oleh International Electrotechnical Commission (IEC) yang mengatur batasan harmonisa pada beban kecil satu fasa ataupun tiga fasa dengan mengggunakan standar IEC61000-3-2, [4],[5].

Adapun standar yang digunakan adalah kelas A yaitu semua kategori beban termasuk didalamnya peralatan penggerak motor dan semua peralatan 3 fasa yang arusnya tidak lebih dari 16 amper perfasanya. Untuk peralatan satu fasa (tegangan kerja $230 \mathrm{~V}$ ) dan tiga fasa $(230 / 400 \mathrm{~V})$ seperti pada Tabel 1.

Tabel 1. Batasan arus harmonisa untuk peralatan kelas A

\begin{tabular}{cc}
\hline $\begin{array}{c}\text { Harmonisa } \\
\text { ke-n }\end{array}$ & $\begin{array}{c}\text { Arus harmonisa maksimum } \\
\text { yang diizinkan (A) } \\
\text { Harmonisa Ganjil }\end{array}$ \\
\hline 3 & 2,30 \\
5 & 1,14 \\
7 & 0,77 \\
9 & 0,40 \\
11 & 0,33 \\
13 & 0,21 \\
$15 \leq \mathrm{n} \leq 39$ & $2,25 / \mathrm{n}$ \\
\hline & Harmonisa Genap \\
4 & 1,08 \\
6 & 0,43 \\
$8 \leq \mathrm{n} \leq 40$ & 0,30 \\
\hline
\end{tabular}

\section{Filter Harmonisa}

Tujuan utama dari filter harmonisa adalah untuk mengurangi amplitudo satu frekuensi tertentu dari sebuah tegangan atau arus. Selain itu filter harmonisa pada frekuensi fundamental dapat mengkompensasi daya reaktif dan dipergunakan untuk memperbaiki faktor daya sistem [21]. 


\section{Filter pasif}

Filter pasif merupakan metode penyelesaian yang efektif dan ekonomis untuk masalah harmonisa, rangkaian filter pasif seperti Gambar 6.

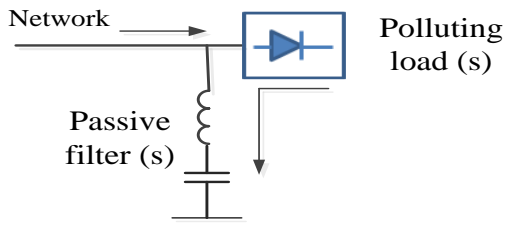

Gbr 6. Filter pasif

Jenis filter pasif, yaitu : (a) Band-Pass, (b) High-Pass, (c) Double Band Pass, (d) Composite [7].

\section{Passive LC filter}

Rangkain passive LC filter untuk inverter tiga fasa seperti Gambar 7.

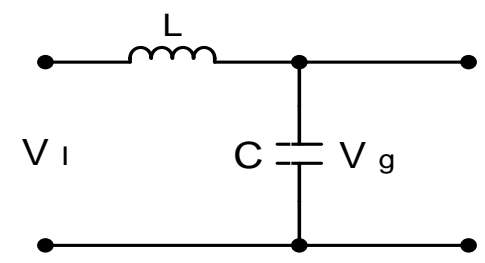

Gbr 7. Rangkaian passive LC filter untuk inverter tiga fasa [8].

\section{Prinsip pereduksian harmonisa dari passive $L C$} filter

Prinsip kerja dari filter shunt (filter pasif paralel) adalah dengan meng-short circuit-kan arus harmonisa yang ada dekat sumber distorsi untuk menjaga arus harmonisa yang masuk tersebut tidak keluar menuju peralatan lain dan sumber suplai energi listrik dan memberikan keuntungan bagi sistem tenaga listrik, yaitu mereduksi harmonisa, memperbaiki $\cos \varphi$ sistem, pada reaktornya berfungsi sebagai filter dan juga melindungi kapasitor dari over kapasitor hal ini dikarenakan adanya resonansi. Sebuah rangkaian LC dipasang pada frekuensi harmonisa sebagai filter, seperti Gambar 8 [7].

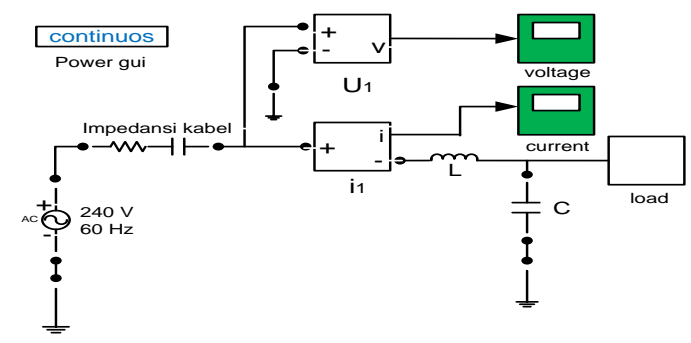

Gbr 8. Pemodelan passive LC filter [7]

\section{Merancang passive LC filter} Gambar 9.

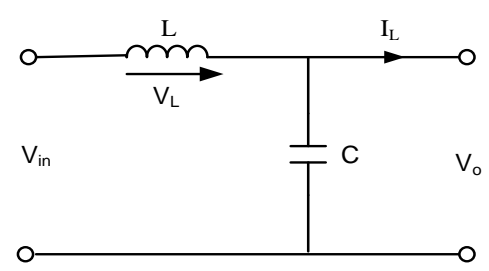

Gbr 9. Rangkaian impedansi passive LC filter [22]

Passive LC filter terdiri dari hubungan paralel komponen-komponen pasif yaitu Induktor dan kapasitor. Dalam mendesain passive LC filter terlebih dahulu menentukan besar kapasitor sesuai kebutuhan faktor daya dan induktor filter. Langkah-langkah yang harus dilakukan dalam merancang passive LC filter adalah sebagai berikut [22],[23] :

A. Menghitung nilai kapasitor ( C )

1) Tentukan ukuran kapasitas kapasitor $Q c$ $\mathrm{Q}_{\mathrm{C}}=\mathrm{P}\left\{\tan \left(\cos ^{-1} \mathrm{pf}_{1}\right)-\tan \left(\cos ^{-1} \mathrm{pf}_{2}\right)\right\}$

2) Tentukan reaktansi kapasitor $\left(X_{C}\right)$ : $X_{C}=\frac{V^{2}}{Q_{C}}$

3) Tentukan kapasitas dari kapasitor ( C )

$$
C=\frac{1}{2 \pi f_{0} X_{C}}
$$

B. Menghitung nilai induktor ( $\mathrm{L}$ )

1) Tentukan nilai impedansi $Z$ induktor [22]:

$$
Z=\frac{V_{S}}{I}
$$

2) Tentukan Reaktansi Induktif dari Induktor [22,23]:

$$
X_{L}=\frac{X_{C}}{h_{n}^{2}}
$$

3) Tentukan reaktansi karakteristik dari filter pada orde tuning:

$$
X_{n}=h_{n} X_{L}
$$

4) Tentukan Tahanan (R) dari Induktor [22,23]:

$$
R=\frac{X_{n}}{Q}
$$

5) Tentukan induktansi dari induktor [23]:

$$
L=\frac{\sqrt{Z^{2}+R^{2}}}{2 \pi f_{0}}
$$

Dari Gambar 9 dapat dicari impedansi rangkain dengan persamaan:

$$
z=\frac{1}{\frac{1}{X_{L}}+\frac{1}{X_{C}}}
$$

\section{Passive single tuned filter}

Passive single-tuned filter adalah filter yang terdiri dari komponen-komponen pasif $\mathrm{R}, \mathrm{L}$ dan $\mathrm{C}$ terhubung seri, seperti pada Gambar 10. Passive singletuned filter akan mempunyai impedansi yang kecil pada frekuensi resonansi sehingga arus yang memiliki frekuensi yang sama dengan frekuensi resonansi akan dibelokkan melalui filter. 


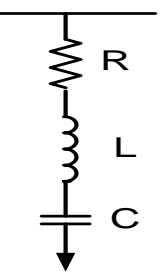

Gbr 10. Passive single tuned filter [9]

Berdasarkan Gambar 10, besarnya impedansi passive single tuned filter pada frekuensi fundamental adalah [5]:

$Z_{F}=R+j\left(X_{L}-X_{C}\right)$

Pada frekuensi resonansi , Persamaan (27) menjadi:

$Z_{F}=R+j\left(\omega_{r} L-\frac{1}{\omega_{r} C}\right)$

Jika frekuensi sudut saat resonansi adalah:

$\omega_{r}=2 \pi f_{0} h_{r}$

Impedansi filter dapat ditulis sebagai berikut:

$Z_{F}=R+j\left(X_{L} h_{r}-\frac{X_{C}}{h_{r}}\right)$

Saat resonansi terjadi nilai reaktansi induktif dan reaktansi kapasitif sama besar, maka diperoleh impedansi passive single tuned filter seperti pada Persamaan (31) adalah

$Z_{F}=R$

Pada Persamaan (31) menunjukkan bahwa pada frekuensi resonansi, impedansi passive single-tuned filter sama dengan tahanan induktor $\mathrm{R}$, sehingga arus harmonisa yang mempunyai frekuensi yang sama dengan frekuensi resonansi akan dialirkan atau dibelokkan melalui passive single-tuned filter. Dengan demikian Passive single tuned filter diharapkan dapat mengurangi $\mathrm{IHD}_{\mathrm{V}}$ dan $\mathrm{IHD}_{\mathrm{i}}$ sampai dengan 10-30\%. Besarnya tahanan $\mathrm{R}$ dari induktor dapat ditetukan oleh faktor kualitas dari induktor. Pada frekuensi tuning:

$\omega_{n} L=\frac{1}{\omega_{n} C}=X_{n}$

Faktor kualitas:

$Q=\frac{X_{n}}{R}$

Berdasarkan persamaan (9), tahanan resistor adalah:

$R=\frac{X_{n}}{Q}$

Prinsip pereduksian harmonisa dari passive singletuned filter

Pada Frekuensi resonansi (fr), Passive single tuned filter memiliki impedansi minimum sebesar nilai resistansi $\mathrm{R}$ dari induktor. Oleh karena itu, filter ini menyerap semua arus harmonik yang dekat dengan frekuensi resonansi (fr) yang diinjeksikan. Ada dua parameter yang perlu dipertimbangkan dalam menentukan nilai $\mathrm{R}, \mathrm{L}$, dan $\mathrm{C}$, yaitu:

1. Faktor kualitas (Quality factor, Q)

2. Penyimpangan frekuensi relative (Relative Frequency Deviation, $\delta$ )

Filter dengan $\mathrm{Q}$ tinggi disetel pada frekuensi rendah (misalnya harmonisa kelima), dan nilainya biasanya terletak antara 30 dan 100. Perkiraan nilai Q untuk reaktor inti udara (air core reactors) adalah 75 dan lebih besar 75 untuk reaktor inti besi (iron-core reactors) [17].
Passive single-tuned filter yang diletakkan secara paralel akan men-short circuit-kan arus harmonisa yang ada dekat dengan sumber distorsi seperti pada Gambar 11. Passive single tuned filter yang merupakan hubungan seri komponen $\mathrm{R}, \mathrm{L}$, dan $\mathrm{C}$ memberikan keuntungan bagi sistem tenaga listrik, yaitu mampu mereduksi tigkat harmonisa, merperbaiki $\cos \varphi$, sedangkan induktor berfungsi sebagai filter, melindungi kapasitor dari over kapasitor akibat adanya resonansi.

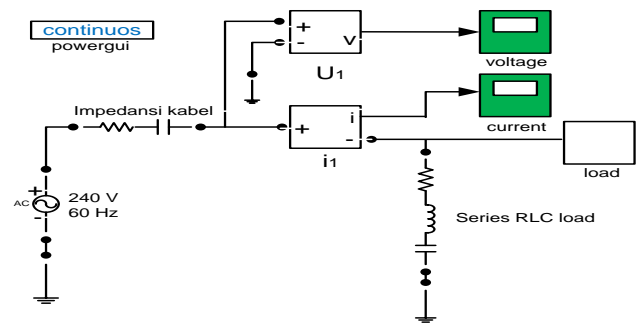

Gbr 11. Pemodelan passive single tuned filter [24]

Pada Gambar 12 diperlihatkan gelombang hasil dari pemfilteran harmonisa dengan menggunakan bantuan simulasi MATLAB/ Simulink untuk menjelaskan proses eliminasi gelombang arus terdistorsi.

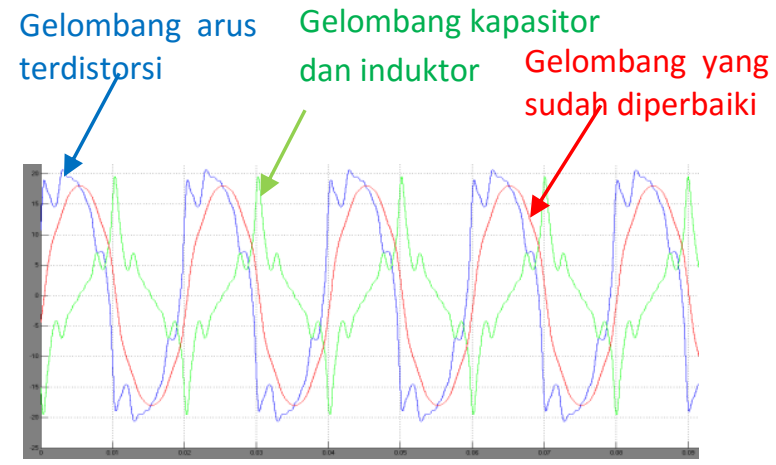

Gbr 12. Kompensasi gelombang filter

\section{Merancang passive single tuned filter}

Mendesain passive single tuned filter yang terdiri dari hubungan seri komponen-komponen pasif induktor, kapasitor dan tahanan seperti Gambar 13, [10], [11],[22].

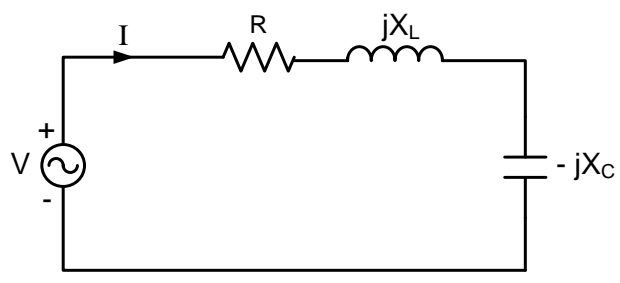

Gbr 13. Rangkaian resonansi seri

Langkah-langkah rancangan passive single tuned filter adalah :

a. Tentukan ukuran kapasitas kapasitor Qc :

$Q_{C}=P\left\{\tan \left(\cos ^{-1} p f_{1}\right)-\tan \left(\cos ^{-1} p f_{2}\right)\right.$ 
b. Tentukan reaktansi kapasitor :

$$
X_{C}=\frac{V^{2}}{Q_{C}}
$$

c. Tentukan kapasitansi dari kapasitor :

$$
C=\frac{1}{2 \pi f_{0} x_{C}}
$$

d. Tentukan reaktansi induktif dari induktor :

$$
\mathrm{X}_{\mathrm{L}}=\frac{\mathrm{X}_{\mathrm{C}}}{\mathrm{h}_{\mathrm{n}}^{2}}
$$

e. Tentukan induktansi dari induktor :

$$
L=\frac{X_{L}}{2 \pi f_{0}}
$$

f. Tentukan reaktansi karakteristik dari filter pada orde tuning :

$X_{n}=h_{n} X_{L}$

g. Tentukan tahanan $(\mathrm{R})$ dari Induktor :

$$
R=\frac{X_{n}}{Q}
$$

Kebutuhan daya reaktif dapat dihitung dengan pemasangan kapasitor untuk memperbaiki faktor daya [23].

Daya Reaktif $(Q)=$ Daya Aktif $(P) \times \tan \varphi$

Daya reaktif pada pf awal yaitu :

$Q_{1}=P x \tan \varphi_{1}$

Daya reaktif pada pf diperbaiki yaitu :

$Q_{2}=P x \tan \varphi_{2}$

Sehingga rating kapasitor yang diperlukan untuk memperbaiki faktor daya yaitu:

Daya reaktif $\Delta Q=Q_{1}-Q_{2}$

Atau

$\Delta Q=P\left(\tan \varphi_{1-} \tan \varphi_{2}\right)$

\section{Metode Penelitian}

Metode yang digunakan dalam penelitian ini adalah melakukan pengukuran harmonisa pada VSD tipe ATV12H075M2 dengan beban motor induksi tiga fasa $750 \mathrm{~W}$. Hasil pengukuran didapat berupa THDv, THDi, IHDv dan IHDi. Selanjutnya dilakukan perhitungan untuk menentukan parameter passive $L C$ filter dan passive single tuned filter kemudian dilakukan pemodelan beban dan filter yang disimulasikan dengan program MATLAB/Simulink. Hasil kedua filter tersebut dibandingkan terhadap standar IEC61000-3-2 Kelas A.

\section{Teknik Pengukuran Yang Dilakukan}

Teknik pengukuran dan pengambilan data menggunakan alat ukur Fluke 435 Power Quality Analyzer yang dilakukan pada PLN Wilayah Sumatera Utara dengan menggunakan rangkaian Gambar 3.2.

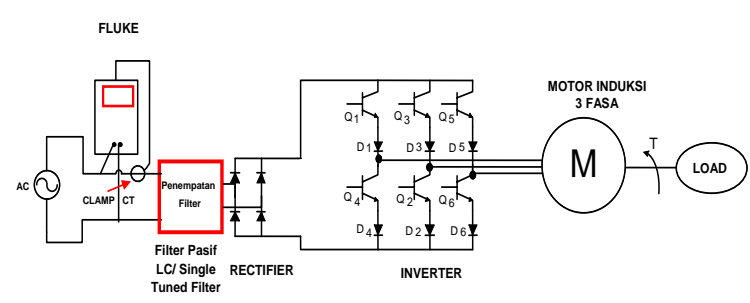

Gbr 14. Diagram penempatan passive LC filter dan passive single tuned filter

\section{Data Hasil Pengukuran}

Tabel 2 merupakan data yang diambil dari pengukuran Variable Speed Drive.

Tabel 2. Data hasil pengukuran

\begin{tabular}{ccc}
\hline \multicolumn{3}{c}{$\begin{array}{c}\text { Variable Speed Drive } \\
\text { dengan daya 750 Watt }\end{array}$} \\
\hline Parameter & Satuan & Nilai \\
\hline S (Apparent Power) & VA & 426.9 \\
P (Active Power) & Watt & 285.6 \\
Q (Reactive Power) & VAR & 317.4 \\
PF (Power Factor) & - & 0.67 \\
THDv & $\%$ & 3.5 \\
THDi & $\%$ & 102.9 \\
Frekuensi & Hz & 50 \\
V (Phase Voltage) & Volt & 219.63 \\
I (Phase Current) & Ampere & 2.402 \\
\hline
\end{tabular}

Pada Tabel 2 ditunjukan bahwa data hasil pengukuran IHDi dan IHDv dari setiap orde harmonisa dalam satuan persen yaitu masing-masing sebesar $102,9 \%$ dan $3,5 \%$ yang dirubah dalam satuan amper dan tegangan.

Jika dibandingkan dengan standar IEC61000-3-

\begin{tabular}{|c|c|c|c|c|c|c|}
\hline \multirow{2}{*}{$\begin{array}{l}\text { Harmonisa } \\
\text { ke-n }\end{array}$} & \multicolumn{4}{|c|}{$\begin{array}{l}\text { Individual Distorsi Harmonisa } \\
\text { (IHD) }\end{array}$} & \multirow{2}{*}{$\begin{array}{r}\text { THDi } \\
(\%)\end{array}$} & \multirow{2}{*}{$\begin{array}{c}\text { THDv } \\
(\%)\end{array}$} \\
\hline & $\begin{array}{r}\text { Arus }( \\
(\%)\end{array}$ & $\begin{array}{l}\text { i) Arus (i) } \\
\text { (Amp) }\end{array}$ & $\begin{array}{r}\text { Tegangan } \\
\text { (V) }(\%)\end{array}$ & $\begin{array}{l}\text { Tegangan } \\
\text { (V) Volt }\end{array}$ & & \\
\hline 3 & 81,3 & 1,95 & 2,4 & 5,27 & & \\
\hline 5 & 52,7 & 1,26 & 2,2 & 4,83 & & \\
\hline 7 & 21,4 & 0,51 & 1,2 & 3,29 & & \\
\hline 9 & 5,2 & 0,12 & 0,5 & 1,09 & 102,9 & 3,5 \\
\hline 11 & 15,3 & 0,36 & 0,3 & 0,65 & & \\
\hline 13 & 14,5 & 0,34 & 0,3 & 0,65 & & \\
\hline 15 & 6,8 & 0,16 & 0,3 & 0,65 & & \\
\hline
\end{tabular}
2 Kelas $A$, ada beberapa orde IHDi pada VSD dari hasil pengukuran yang tidak sesuai dengan standar.

Tabel 3. Data hasil pengukuran harmonisa arus dan tegangan

Bentuk gelombang, spektrum arus dan tegangan pada Gambar 3.3 s/d 3.5. Di mana pada Gambar 15 bentuk gelombang arus dan tegangan yang tidak sinusoidal.

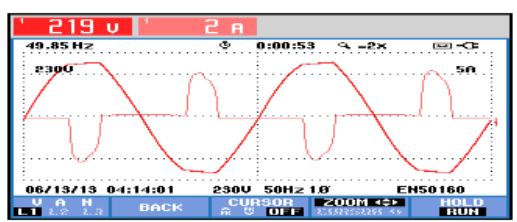


Gbr 15. Bentuk gelombang arus dan tegangan.
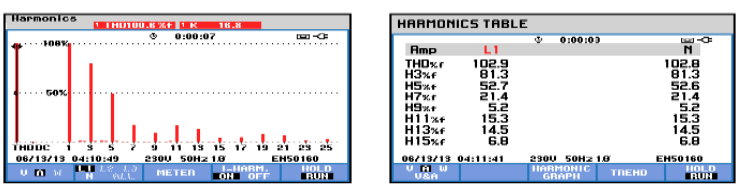

Gbr 16. Bentuk spectrum Gbr 17 . Individual distorsi harmonisa arus harmonisa arus

\section{Perbandingan Klasifikasi Arus Harmonisa Pada} VSD Berdasarkan Standar IEC61000-3-2 Kelas A

Sebelum merancang filter sebaiknya diketahui terlebih dahulu orde arus harmonisa mana yang tidak sesuai standar. Pada Tabel 3.3 dapat dilihat klasifikasi arus harmonisa pada VSD dari hasil pengukuran berdasarkan standar IEC61000-3-2 Kelas A.

Tabel 4. Perbandingan arus harmonisa pengukuran pada VSD dengan standar IEC61000 3-2 kelas A

\begin{tabular}{cccc}
\hline $\begin{array}{c}\text { Harmonisa } \\
\text { ke-n }\end{array}$ & $\begin{array}{c}\text { Arus harmonisa } \\
\text { Standar } \\
\text { IEC61000-3-2 } \\
\text { kelas A (Amper) }\end{array}$ & $\begin{array}{c}\text { Arus Harmonisa VSD } \\
\text { Hasil Pengukuran } \\
\text { (Amper) }\end{array}$ & Keterangan \\
\hline 3 & 2,30 & 1,95 & Sesuai \\
5 & 1,14 & 1,26 & Tidak sesuai \\
7 & 0,77 & 0,51 & Sesuai \\
9 & 0,40 & 0,12 & Sesuai \\
11 & 0,33 & 0,36 & Tidak sesuai \\
13 & 0,21 & 0,34 & Tidak sesuai \\
15 & 0,15 & 0,16 & Tidak sesuai \\
\hline
\end{tabular}

\section{Perhitungan Nilai L dan C dari Passive LC Filter}

Dalam menentukan besarnya parameter passive $L C$ filter yang dibutuhkan, terlebih dahulu diperhatikan nilai selisih terbesar dari orde harmonisa arus. Dari Tabel 2 selisih terbesar terdapat pada orde harmonisa ke-5, oleh karena itu passive LC filter yang digunakan adalah filter untuk harmonisa ke-5.

a. Perhitungan pemakaian arus beban

Dalam menghitung pemakaian arus beban pada VSD dengan daya 285,6 watt (Tabel 2) yaitu :

$I=\frac{285,6}{219,63 \times 0,67}=1,9408$ Amper

Jika dari data pengukuran Tabel 3.1 dengan pemakaian arus sebesar 2,402 Ampere, pada tegangan kerja 219,63 Volt, dan faktor daya 0,67, maka pemakaian daya kondisi tersebut sebesar:

$\mathrm{P}=219,63 \times 2,402 \times 0,67=352,45 \mathrm{watt}$

Dengan demikian persentasi beroperasinya daya VSD sebesar $47 \%$ dari $750 \mathrm{~W}$, jika terperbaiki faktor daya sistem menjadi 0,95, maka arus yang mengalir sebesar, $\frac{352,45}{219,63 \times 0,95}=1,689 \mathrm{~A}$

Sehingga arus akan lebih kecil mengalir sebesar 70,32 $\%$ dari $2,402 \mathrm{~A}$.

\section{b. Perhitungan nilai $\mathrm{C}$}

Untuk memperbaiki faktor daya dari 0,67 menjadi 0,95 dengan menggunakan Tabel 2 dibutuhkan kapasitas kapasitor sebesar :

$Q_{C}=P\left\{\tan \left(\cos ^{-1} p f_{1}\right)-\tan \left(\cos ^{-1} p f_{2}\right)\right.$

$Q c=222,4824$ Var

Sehingga nilai reaktansi kapasitor :

$X c=\frac{V^{2}}{Q_{C}}=\frac{219,63^{2}}{222,4824}=216,81417 \Omega$

Maka besar nilai $\mathrm{C}$ yaitu :

$\mathrm{C}=\frac{1}{2 \pi \mathrm{f}_{0} \mathrm{X}_{\mathrm{C}}}=14,689 \mu \mathrm{F}$

c. Perhitungan nilai L

Menentukan nilai L sebagai filter, dengan memasukan nilai dari pengukuran pada Tabel 3 .

Nilai impedansi $Z$, di mana:

$Z=\frac{V_{s}}{I}$

Dari Tabel 2 di dapat arus $I=2,402$ Amper pada faktor daya 0,67 , maka

$Z=\frac{219,63}{2,402}=91,43 \Omega$

Reaktansi induktif dari induktor:

$\mathrm{X}_{\mathrm{L} 3}=\frac{\mathrm{X}_{\mathrm{C}}}{\mathrm{h}_{3}^{2}}=\frac{216,81417}{3^{2}}=24,0905 \Omega$

Reaktansi karakteristik dari filter pada orde tuning:

$X_{n}=5 \times 8.6726=43.363 \Omega$

Tahanan (R) dari Induktor:

$R=\frac{X_{n}}{Q}=\frac{43,363}{100}=0,43363 \Omega$

Jadi induktansi dari induktor $(\mathrm{L})$ :

$L=\frac{\sqrt{Z^{2}+R^{2}}}{2 \pi f_{0}}=0,2912 \mathrm{H}$

Dari perhitungan diatas diperoleh parameter filter LC adalah :

$\mathrm{C}=15 \mu \mathrm{F}$ dan $\mathrm{L}=0.2912 \mathrm{H}$

Impedansi rangkaian:

$Z_{3}=\frac{X_{L} \times X_{C}}{X_{L}+X_{C}}=21,68$

\section{Perhitungan Nilai $\mathrm{R}, \mathrm{L}$ dan $\mathrm{C}$ dari Passive Single Tuned Filter}

Menentukan kebutuhan kapasitor sebagai perbaikan faktor daya, dengan memasukan nilai dari pengukuran pada Tabel 3.1. Untuk memperbaiki faktor daya dari 0,67 menjadi 0,95 dibutuhkan kompensasi kapasitor sebesar :

a. Kapasitas kapasitor $Q_{C}=P\left\{\tan \left(\cos ^{-1} p f_{1}\right)-\tan \left(\cos ^{-1} p f_{2}\right)\right.$ $Q c=222,4824$ Var

b. Nilai reaktansi kapasitor : $X c=\frac{V^{2}}{Q_{C}}=\frac{219,63^{2}}{222,4824}=216,81417 \Omega$

c. Kapasitansi dari kapasitor ( C ): 


$$
\mathrm{C}=\frac{1}{2 \pi \mathrm{f}_{0} \mathrm{x}_{\mathrm{C}}}=14,689 \mu F
$$

d. Nilai reaktansi induktif dari induktor $\left(X_{L}\right)$ yaitu :

$\mathrm{X}_{\mathrm{L} 3}=\frac{\mathrm{X}_{\mathrm{C}}}{\mathrm{h}_{3}^{2}}=\frac{216,81417}{3^{2}}=24,0905 \Omega$

Induktansi dari induktor (L) :

$$
\begin{aligned}
& L_{n}=\frac{X_{L n}}{2 \pi f_{0}} \\
& L_{3}=\frac{24,0905}{2 \times 3,14 \times 50}=0,0767 \mathrm{H}
\end{aligned}
$$

e. Nilai reaktansi karakteristik dari filter $\left(X_{n}\right)$ yaitu :

$X_{n}=h_{n} X_{L n}$

$X_{3}=3 \times 24,0905=72,2715 \Omega$

f. Nilai tahanan ( $\mathrm{R}$ ) dari induktor :

$$
\begin{aligned}
& R_{n}=\frac{X_{n}}{Q} \\
& R_{3}=\frac{72,2715}{100}=0,72272 \Omega
\end{aligned}
$$

Pada frekuensi harmonisa ke 3 dimana filter dituned, maka impedansi yang dihasilkan adalah:

$$
\begin{aligned}
& Z_{n}=R_{n}+j\left(2 \pi f_{n} L_{n}-\frac{1}{2 \pi f_{n} C}\right) \\
& Z_{3}=0,72272+j(0,0548) \\
& {[Z\rfloor_{3}=0,7238 \Omega}
\end{aligned}
$$

\section{Diagram Simulasi MATLAB/Simulink}

Untuk membuat simulasi MATLAB/ Simulink digunakan data hasil pengukuran besaran daya, tegangan, arus RMS, IHD ${ }_{\text {i }}$ pada setiap orde harmonisa pada VSD, serta hasil perhitungan nilai - nilai RLC dari passive LC filter dan passive single tuned filter.

Pada Gambar 3.8 diagram simulasi rangkaian VSD sebelum pemakain filter. Bentuk gelombang arus dan spectrum arus diperoleh dari Block Power GUI bagian Fast Fourier Transform (FFT) analysis diperlihatkan pada Gambar 3.9 dan 3.10.

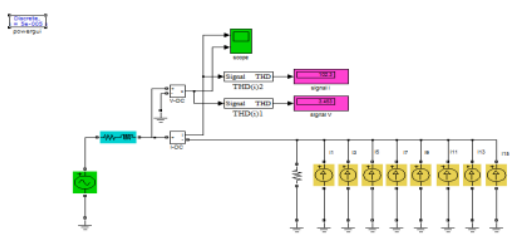

Gbr 18. Simulasi VSD sebelum pemasangan filter

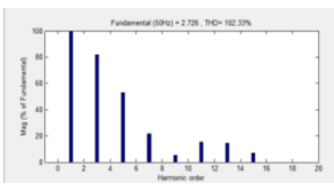

Gbr 19. Gelombang arus simulasi sebelum pemasangan filter

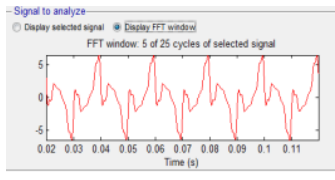

Gbr 20. Spektrum arus simulasi sebelum pemasangan filter
Terjadi cacat gelombang arus yang menyebabkan gelombang VSD jauh dari gelombang sinusoidal, sehingga diupayakan untuk mereduksi harmonisa arus pada VSD dengan menggunakan passive LC filter dan passive single tuned filter dengan hubungan sebagai berikut :

a. Passive LC filter terdiri dari $\mathrm{L}$ dan $\mathrm{C}$ dipasang paralel dengan beban, seperti Gambar 21.

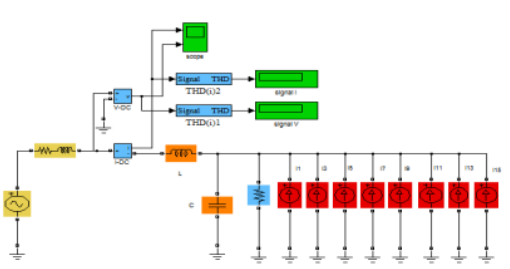

Gbr 21. Simulasi VSD dengan Passive LC filter

b. Passive single tuned filter terdiri dari resistansi, induktor dan kapasitor dipasang paralel dengan beban, seperti Gambar 22.

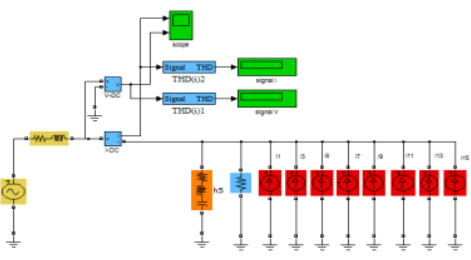

Gbr 22. Simulasi VSD dengan passive single tuned filter

\section{Hasil Dan Pembahasan}

Simulasi yang digunakan pada penelitian ini adalah menggunakan program MATLAB/Simulink dengan menggunakan passive LC filter dan passive single tuned filter yang dipasang paralel terhadap rangkaian, kemudian membandingkan kedua filter tersebut terhadap nilai $\mathrm{IHD}_{\mathrm{i}}$ yang telah diredam oleh filter, dimana sebelum dipasang filter $T H D_{i}$ sebesar $102,9 \%$ dan setelah pemasangan passive LC filter dan passive single tuned filter berturut-turut THDi nya $23,78 \%$ dan $8,79 \%$.

\section{Harmonisa Arus Setelah Pemasangan Passive LC Filter}

THDi hasil pengukuran dari VSD adalah 102,9\%. Setelah pemasangan passive LC filter diperoleh THDi berkurang menjadi $23,78 \%$ atau tereduksi sebesar $79,12 \%$. Bentuk gelombang arus dan spektrum harmonisa arus setelah pemasangan passive LC filter dapat di lihat pada Gambar 4.1 dan 4.2. Bentuk gelombang yang dihasilkan tidak sinusoidal, ini menunjukkan bahwa pada gelombang masih terdapat harmonisa tetapi kandungan harmonisanya lebih kecil dibandingkan dengan bentuk gelombang sebelum pemakaian passive LC filter.

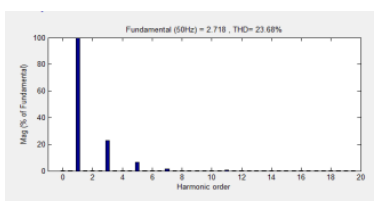

Gbr 23. Bentuk gelombang arus passive LC filter

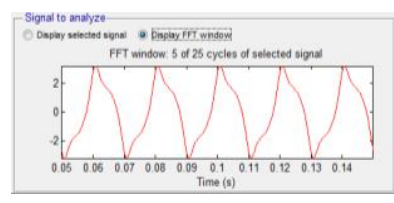

Gbr 24. Spektrum harmonisa arus passive LC filter 
Dari Tabel4 telah diketahui bahwa terdapat empat orde harmonisa yang tidak sesuai standar IEC61000-3-2 Kelas A. Setelah pemasangan passive $L C$ filter nilai arus harmonisa berkurang dan memenuhi standar IEC61000-3-2 kelas A seperti pada (Tabel 5)

Tabel 5. Perbandingan arus harmonisa pengukuran pada VSD setelah pemasangan passive $L C$ filter dengan standar IEC61000-3-2 kelas A

\begin{tabular}{|c|c|c|c|}
\hline $\begin{array}{c}\text { Harmonisa } \\
\text { ke-n }\end{array}$ & $\begin{array}{c}\text { Arus harmonisa } \\
\text { maksimum Standar } \\
\text { IEC61000-3-2 } \\
\text { kelas A Yang di } \\
\text { izinkan (Amper) }\end{array}$ & $\begin{array}{l}\text { Arus Harmonisa } \\
\text { VSD Setelah } \\
\text { Pemasangan } \\
\text { Passive LC } \\
\text { Filter (Amper) }\end{array}$ & Keterangan \\
\hline 3 & 2,30 & 0,55 & Sesuai standar \\
\hline 5 & 1,14 & 0,16 & Sesuai standar \\
\hline 7 & 0,77 & 0,04 & Sesuai standar \\
\hline 9 & 0,40 & 0,007 & Sesuai standar \\
\hline 11 & 0,33 & 0,012 & Sesuai standar \\
\hline 13 & 0,21 & 0,008 & Sesuai standar \\
\hline 15 & 0,15 & 0,003 & Sesuai standar \\
\hline \multicolumn{2}{|r|}{ THDi (\%) } & $23,78 \%$ & \\
\hline
\end{tabular}

\section{Harmonisa Arus Setelah Pemasangan Passive Single Tuned Filter.}

THDi hasil pengukuran dari VSD adalah $102,9 \%$. Setelah pemasangan passive single tuned filter diperoleh THDi berkurang menjadi 8,78\% atau tereduksi sebesar 94,12\%. Bentuk gelombang arus dan spektrum harmonisa arus setelah pemakaian passive single tuned filter dapat dilihat pada Gambar 25 dan 26. Bentuk gelombang yang dihasilkan tidak sinusoidal, ini menunjukkan bahwa pada gelombang masih terdapat harmonisa tetapi kandungan harmonisanya lebih kecil.

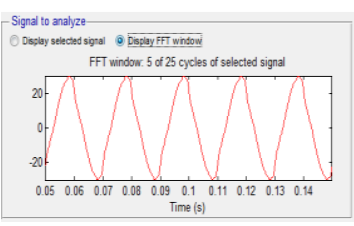

Gbr 25. Bentuk gelombang arus passive single tuned filter

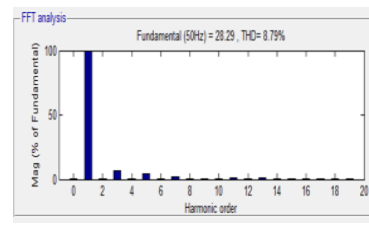

Gbr 26. Spektrum harmonisa arus passive single tuned filter
Dari Tabel 4 telah diketahui bahwa terdapat empat orde harmonisa yang tidak sesuai standar IEC61000-3-2 Kelas A. Setelah pemasangan passive single tuned filter nilai arus harmonisa berkurang dan memenuhi standar IEC61000-3-2 kelas A seperti yang dapat dilihat pada Tabel 6

Tabel 6. Perbandingan arus harmonisa pengukuran pada VSD setelah pemasangan passive single tuned filter dengan standar IEC61000-3-2 kelas A

\begin{tabular}{cccc}
\hline $\begin{array}{c}\text { Harmonisa } \\
\text { ke-n }\end{array}$ & $\begin{array}{c}\text { Arus harmonisa } \\
\text { maksimum Standar } \\
\text { IEC61000-3-2 } \\
\text { kelas A Yang di } \\
\text { izinkan (Amper) }\end{array}$ & $\begin{array}{c}\text { Arus Harmonisa } \\
\text { VSD Setelah } \\
\text { Pemasangan Single } \\
\text { Tuned Filter } \\
\text { (Amper) }\end{array}$ & Keterangan \\
\hline 3 & 2,30 & 0,215 & Sesuai standar \\
5 & 1,14 & 0,111 & Sesuai standar \\
7 & 0,77 & 0,045 & Sesuai standar \\
9 & 0,40 & 0,011 & Sesuai standar \\
11 & 0,33 & 0,032 & Sesuai standar \\
13 & 0,21 & 0,031 & Sesuai standar \\
15 & 0,15 & 0,014 & Sesuai standar \\
\hline \multicolumn{4}{c}{ THDi } \\
\hline
\end{tabular}

Perbandingan Hasil Simulink Passive LC filter dan Passive single tuned filter untuk Mereduksi Harmonisa Arus pada VSD

Perbandingan hasil harmonisa dengan menggunakan passive LC filter dan passive single tuned filter untuk mereduksi harmonisa pada VSD dengan penurunan THDi, IHD IH $_{\mathrm{i}}$ pada setiap orde harmonisa dapat dilihat pada Tabel 7.

Tabel 7. Perbandingan arus harmonisa pada VSD sebelum dan sesudah pemasangan filter

\begin{tabular}{|c|c|c|c|c|}
\hline $\begin{array}{l}\text { Harmo } \\
\text { nisa } \\
\text { ke-n }\end{array}$ & $\begin{array}{c}\text { Standar } \\
\text { IEC61000-3-2 } \\
\text { kelas } A \\
\text { (Amper) }\end{array}$ & $\begin{array}{c}\text { Sebelum } \\
\text { Pemasangan } \\
\text { Filter } \\
\text { (Amper) }\end{array}$ & $\begin{array}{c}\text { Setelah } \\
\text { Pemasangan } \\
\text { Filter Pasif } \\
\text { LC (Amper) }\end{array}$ & $\begin{array}{c}\text { Setelah } \\
\text { Pemasangan } \\
\text { Pasissive } \\
\text { Single Tuned } \\
\text { Filter (Amper) }\end{array}$ \\
\hline 3 & 2,30 & 1,95 & 0,55 & 0,215 \\
\hline 5 & 1,14 & 1,26 & 0,16 & 0,111 \\
\hline 7 & 0,77 & 0,51 & 0,04 & 0,045 \\
\hline 9 & 0,40 & 0,12 & 0,007 & 0,011 \\
\hline 11 & 0,33 & 0,36 & 0,012 & 0,032 \\
\hline 13 & 0,21 & 0,34 & 0,008 & 0,031 \\
\hline 15 & 0,15 & 0,16 & 0,003 & 0,014 \\
\hline \multicolumn{2}{|c|}{ THDi (\%) } & $102,9 \%$ & $23,78 \%$ & $8,79 \%$ \\
\hline
\end{tabular}

Untuk lebih jelas Tabel 8 dibuat dalam bentuk grafik seperti Gambar 27. Terlihat dari grafik tersebut yang paling baik untuk mereduksi arus harmonisa pada VSD adalah passive single tuned filter dibanding dengan passive LC filter, karena impedansi passive single tuned filter lebih kecil dari impedansi passive $L C$ filter, seperti pada Gambar 28 dan 29. Secara keseluruhan THDi yang dihasilkan peralatan telah dapat diturunkan dengan menggunakan passive $L C$ filter dan passive single tuned filter.

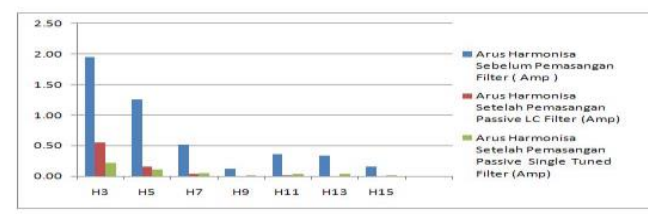

Gbr 27. Diagram perbandingan sebelum dan sesudah pemasangan filter. 


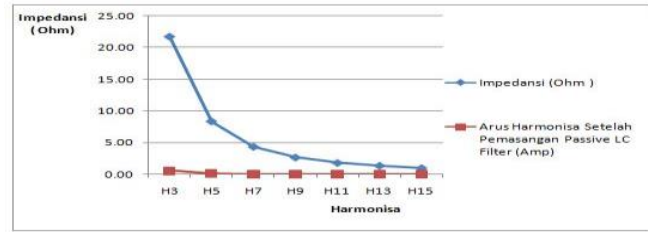

Gbr 28. Grafik hubungan impedansi dengan harmonisa arus passive LC filter

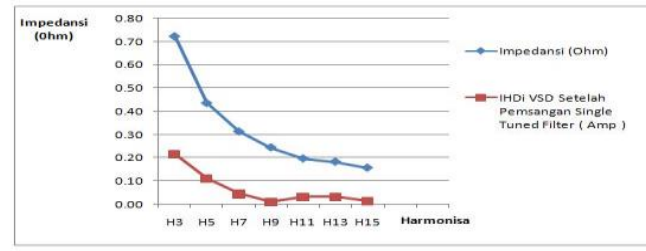

Gbr 29. Grafik hubungan impedansi dengan harmonisa arus passive single tuned filter

\section{Kesimpulan Dan Saran}

\section{Kesimpulan}

1. Varable Speed Drive yang diukur menghasilkan THDi sebesar 102,9\% dengan beberapa orde harmonisa arus yang tidak sesuai standar IEC61000-3-2 Kelas A, yaitu orde ke-5, orde11 , orde-13, dan orde ke-15

2. Setelah pemasangan passive LC filter , THDi pada VSD berkurang dari $102.9 \%$ menjadi $23,68 \%$ atau tereduksi $79,22 \%$,

3. Setelah pemasangan passive single tuned filter , THDi pada VSD berkurang dari $102.9 \%$ menjadi menjadi $8,79 \%$ atau tereduksi sebesar $94,11 \%$.

4. Passive single tuned filter lebih baik mereduksi harmonisa dibandingkan dengan passive LC filter , karena impedansi passive single tuned filter lebih kecil dari passive LC filte, untuk harmonisa ke 5 yaitu $0,436 \Omega$ dan $8,34 \Omega$.

5. Passive single tuned filter lebih baik mereduksi harmonisa dibandingkan dengan passive LC filter , yaitu THDi Passive single tuned filter 8,79\%, sedang pada passive LC filter $23,78 \%$.

\section{Saran}

1. Peneliti selanjutnya untuk menggunakan filter lainnya untuk mereduksi harmonisa VSD.

2. Kepada pabrik pembuat VSD agar memberlakukan standar IEC61000-3-2 kelas A untuk mengurangi harmonisa sebelum diproduksi.

\section{Daftar Pustaka}

1. Mohan, Ned, Undeland, Tore M. and Robbins, William P., 1995.Power electronics Converters, Application, and Design. John Wiley and Sons, Inc.

2. Rijono,Yon. 1997. Dasar Teknik Tenaga Listrik. ANDI. Yogyakarta .

3. Wijaya Mochtar. 2001. Dasar-dasar Mesin Listrik. Djambatan. Jakarta.
4. Basu Supriatim, Bollen. J. H. M, Undeland M. Tore, 2008, PFC Strategies in Light of EN 61000-32, Norwegian University of Science and Techology Trondheim, Norway, Paper Indentification Number A123656, pp:1-9.

5. Francisco C De La Rosa, 2006, Harmonic And Power System, by Taylor \& Francisco Group LLC, Boca Raton London, New York.

6. Dahono A. Pekik, Purwandi, Qamaruzzaman, 1995, An LC Filter Design Method for single-Phase PWM Inverter, IEEE, catalogue no. 95 ${ }^{\text {TH }} 80250-7803$ 2423-4/95/. Pp. 571-576.

7. Rasyid Harun, Kajian pemasangan filter pasif sebagai pereduksi efek harmonisa, Jurnal ELTEK, vol. 04, no. 02, Oktober 2006.

8. H.Ahmed Khaled, J. Finney Stephen and W. Williams Barry, 2007, Passive Filter Design For Three-Phase Inverter Interfacing in Distributed Generation, Electrical Power Quality and Utilisation, Journal Vol. XIII, No. 2, 2007, pp.4958.

9. Chang, G.W, S.Y. Chu, and H.L. Wang, 2002, A New Approach for Placement of Single-Tuned Passive Harmonic Filter in a Power System, IEEE, pp. 814-817.

10. Cho, Young-Sik and Hanju Cha, 2011, Singletuned Passive Harmonic Filter Design Considering Variances of Tuning and Quality Factor, Journal of International Council on Electrical Engineering Vol. 1, No. 1, pp. 7-13.

11. Endy Sopyandi, 2010, Perancangan single-tuned filter untuk mereduksi arus dengan simulasi program ETAP Powerstation 5.0.3, Electrical Engineering Department, University of Indonesia.

12. Schneider Electric Manual Book, April 2009, Altiva 12 Variable Speed Drives for asynchronous motors user manual.

13. Zuhal, 1988, Dasar teknik Tenaga Listrik dan Elektronika Daya, PT. Gramedia, Jakarta.

14. Muhammad H, Rasyid, 1993, Power Electronics Circuit, Devices, and Applications Second Edition, New Jersey : Prentice Hall,Upper Saddle River.

15. Sabirin Taufiq, 2010, Variable Speed Drive Part 1, www.taufiqsabirin. wordpress. com/2010/08/04/variable-speed- drive-part-1.

16. Muhammad H, Rashid, 2004, Power Electronics, Circuit Devices and Application,,Third Edition, Prentice Hall.

17. Jose R. Rodriguez, Juan W. Dixon, Jose R. Espinoza, Jorge Pont, Pablo Lezana, 2005, PWM Regenerative Rectifiers: State of the Art, IEEE transaction on industrial electronics, vol. 52, No.1, Februari 2005, pp 5-21.

18. Johan Lundquist, 2001, On Harmonic Distortion in Power Systems, Departement Electric Power Engineering, Chalmers University of Technology, Goteborg, Sweden.

19. A.Priyadharshini, N.Nevarajan,AR. Uma Saranya, R.Anitt " Survey of Harmonics in Non Linear Loads" International Journal of Recent Technology and Engineering Vol.1, Issue 1, 2012. 
20. Grady Mack, Understanding Power System Harmonic, University of Texas at Austin, 2005.

21. Basu Supratim, 2006, Single Phase Active Power factor Correction Converter, Chalmers University Technology, Goteborg, Sweden June.

22. Wakileh G.J, 2001, Power System Harmonics: Fundamental, Analysis and Filter Design, Springer Velag Press.

23. D.A. Gonzales and J.C. McCall, 1987, Design of Filter to Reduce Harmonic Distortion in Industrial Power System, IEEE Trans Ind. Application, Vol 1A-23, pp. 504-511. 130-134.

24. Rizkytama, Ardian, 2010, Perencanaan High Pass dan Single Tuned Filter Sebagai Filter Harmonisa Pada Sistem Kelistrikan Tabang Coal Upgrading Plant (TCUP) Kalimantan Timur, Proceedings Institut Teknologi Sepuluh November, Surabaya 